
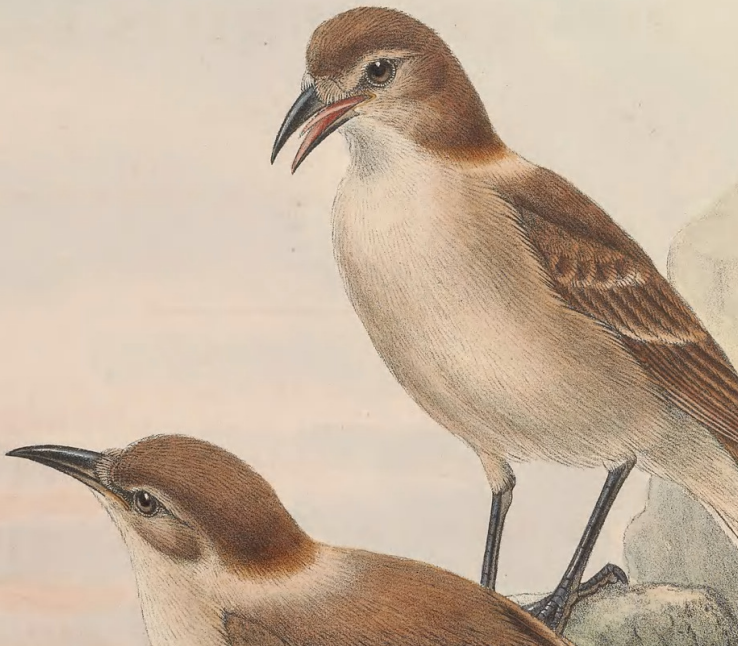

$\frac{4}{2}=\sqrt{x+2}$
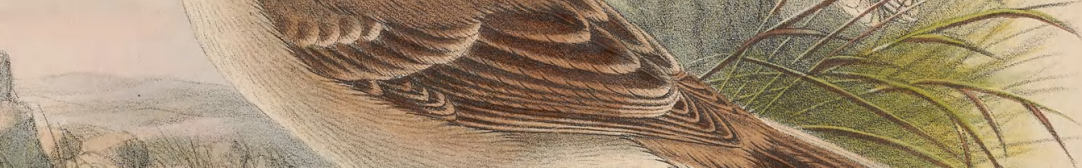

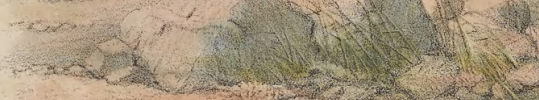
$\cos x+5=25 \pi$

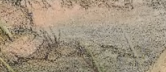
$-x>3+2+2$

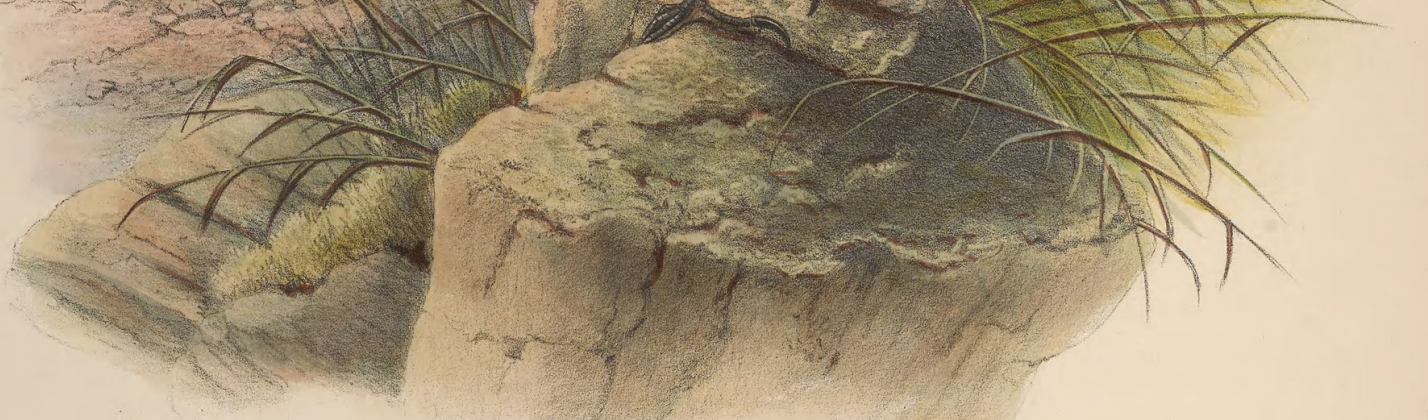




\section{PODOCES HUMILIS, Hume.}

\section{Dingy Podoces.}

Podoces humilis, Hume, Ibis, 1871, p. 408.-Hume \& Henderson, 'Lahore to Yarkand,' p. 247, pl, 23 (1873). -Hume, Stray Feathers, ii.p. 452.

I AGREE with Mr. Hume in referring this plain-coloured bird also to the genus Podoces; but it lacks the ornamental colouring of $P$. Hendersoni and P. Panderi. As will be seen below, it is a bird of somewhat different habits to the other species, and is further distinguished by a difference in the length of bill in the two sexes.

The following short note by Dr. Henderson $(l . c$.$) gives all that is known respecting the habits of this$ curious species :-

"This strange bird was only seen above Kitchik-Yilák, on the way to Yarkand ; on the return journey it was not met with. It frequents short grassy downs, at a height of about 1100 feet. They were not in flocks, but were scattered all over the hill-side."

More recently, Mr. Hume has recorded this species from the borders of Sikkim. His original description is given below, and figures of the bill and wings will be found in the elaborate work above referred to.

"Male.-Forehead, lores, and an indistinct streak over the fore part of the eye fulvous white; front, top, and back of the head, back, scapulars, and rump a dull earthy brown; a broad yellowish-white patch upon the nape; the four central tail-feathers blackish brown, tipped and margined with a paler hue; lateral tailfeathers white, tipped and margined on exterior webs with dingy fulvous; wings brown, the quills slightly darker brown, narrowly margined and tipped with paler brown; lower parts dingy fulvous white. Total length $7 \cdot 5$ inches; bill at front 0.97 to 1 ; wing 3.75 ; tail $2 \cdot 8$; tarsus $1 \cdot 25$."

Mr. Hume adds :- "The female has more of a rufescent tinge on the back and scapulars than the male, and has the quills a darker hair-brown, the tertiaries and some of the secondaries more distinctly margined with a pale rufescent brown. In both sexes the bastard wing appears to be a dark hair-brown. Total length 7 inches; bill from front 0.75 ; wing 3.55 ; tail 2.4 ; tarsus $1 \cdot 3$. It will be noticed that the female is smaller in most of her dimensions, and has the bill conspicuously shorter."

The birds are represented in the Plate of the size of life. 


\section{$2 \mathrm{BHL}$ Biodiversity Heritage Library}

Gould, John. 1875. "Dingy Podoces, Podoces humilis, Hume. [PI. 63]." The Birds of Asia 5(XXVII), -. https://doi.org/10.5962/p.323142.

View This Item Online: https://www.biodiversitylibrary.org/item/121124

DOI: https://doi.org/10.5962/p.323142

Permalink: https://www.biodiversitylibrary.org/partpdf/323142

\section{Holding Institution}

Smithsonian Libraries

\section{Sponsored by}

Smithsonian Institution Libraries

\section{Copyright \& Reuse}

Copyright Status: Not in copyright

This document was created from content at the Biodiversity Heritage Library, the world's largest open access digital library for biodiversity literature and archives. Visit BHL at https://www.biodiversitylibrary.org. 